(C) Group of authors, 2021

UDC $616.31-612.089 .61$

DOI - https://doi.org/10.14300/mnnc.2021.16039

ISSN - 2073-8137

\title{
PERSONALIZED APPROACH TO THE CHOICE OF ORTHOPEDIC DESIGN DEPENDING ON THE PREDICTED STABILITY OF IMPLANTS
}

\author{
REMIZOVA A. A. ${ }^{1}$, DZGOEVA M. G. ${ }^{1}$, SIRAK S. V. ${ }^{2}$, \\ BITAROV P. A. ${ }^{1}$, SIRAK A. G. ${ }^{2}$, TINGAEVA YU. I. ${ }^{1}$, ANDREEV A. A. ${ }^{2}$ \\ ${ }^{1}$ North Ossetian State Medical Academy, Vladikavkaz, Russian Federation \\ 2 Stavropol State Medical University, Russian Federation
}

\section{ПЕРСОНААИЗИРОВАННЫЙ ПОАХОА К ВЫБОРУ ОРТОПЕАИЧЕСКОЙ КОНСТРУКЦИИ В ЗАВИСИМОСТИ ОТ ПРОГНОЗИРУЕМОЙ СТАБИАЬНОСТИ ИМПААНТАТА}

\author{
А. А. РЕМИЗОВА ${ }^{1}$, М. Г. АЗГОЕВА ${ }^{1}$, С. В. СИРАK ${ }^{2}$ \\ П. А. БИТАРОВ ${ }^{1}$, А. Г. СИРАК ${ }^{2}$, Ю. И. ТИНЬГАЕВА ${ }^{\prime}$, А. А. АНАРЕЕВ ${ }^{2}$ \\ 1 Северо-Осетинская госуаарственная меАицинская акалемия, \\ ВлаАикавказ, Российская ФеАерация \\ 2 Ставропольский госуАарственный МеАицинский университет, \\ Российская ФеАерация
}

The stability of 425 implants replacing missing maxillary and mandibular molars and premolars in 126 patients of different ages was evaluated. It was found that dental implants placed in patients aged over 65 years in the chewing teeth group were significantly less stable after 3 and 6 months than those in younger age groups. All the examined groups exhibited a tendency for the secondary stability of implants to decrease in a distal direction. In patients aged over 55 years, it is recommended to install implants to replace each missing tooth as soon as possible. When choosing the most optimal prosthesis design, it is recommended to register the degree of change in the mechanical and biological stability of dental implants at different stages of osseointegration.

Keywords: implant stability, osseointegration, Penguin RFA, osteoplastic materials

Проведена оценка состояния стабильности 425 имплантатов в боковых отделах зубных рядов перед ортопедическим лечением у 126 пациентов в зависимости от возраста и сопутствующих факторов риска. Установлено, что остеоинтеграция у пациентов после 65 лет в области жевательной группы зубов значительно ниже в сравнении с младшими возрастными группами. Выявлена тенденция к снижению стабильности имплантатов по направлению к дистальным участкам челюстей во всех обследованных группах. В возрастной группе старше 55 лет рекомендована установка имплантатов на каждый отсутствующий зуб, а также целесообразно в процессе удаления моляров использовать остеоиндуктивные препараты, позволяющие увеличить плотность костной ткани в указанных областях.

Ключевые слова: стабильность имплантата, остеоинтеграция, Penguin RFA, остеопластические материалы

For citation: Remizova A. A., Dzgoeva M. G., Sirak S. V., Bitarov P. A., Sirak A. G., Tingaeva Yu. I., Andreev A. A PERSONALIZED APPROACH TO THE CHOICE OF ORTHOPEDIC DESIGN DEPENDING ON THE PREDICTED STABILITY OF IMPLANTS. Medical News of North Caucasus. 2021;16(2):173-176. DOI - https://doi.org/10.14300/mnnc.2021.16039

Для цитирования: Ремизова А. А., Дзгоева М. Г., Сирак С. В., Битаров П. А., Сирак А. Г., Тиньгаева Ю. И., Андреев А. А. ПЕРСОНАЛИЗИРОВАННЫЙ ПОДХОД К ВЫБОРУ ОРТОПЕДИЧЕСКОЙ КОНСТРУКЦИИ В ЗАВИСИМОСТИ ОТ ПРОГНОЗИРУЕМОЙ СТАБИЛЬНОСТИ ИМПЛАНТАТА. Медицинский вестник Северного Кавказа. 2021:16(2):173176. DOI - https://doi.org/10.14300/mnnc.2021.16039

omprehensive studies of the process of osseointegration have significantly expanded the indications for the use of dental implants $[1,2]$. The ability of bone tissue to remodel affects the intensity of osseointegration and determines the further stability of the dental implant and, consequently, the service life of the entire orthopedic structure [3-5]. The increase in the operating time of orthopedic structures on dental implants dictates the need to search for new objective methods for assessing the quality of their stability $[3,6]$. However, the variety of implantable materials offered in the market requires clinicians to use high-quality methods for predicting the effective osseointegration of dental implants, taking into account a personalized approach to assessing as many risk factors of the patient as possible at each stage of orthopedic treatment. Among such methods, the frequency-resonance analysis (RFA) method has shown its effectiveness in clinical practice for implantation systems of various manufacturers $[7,8]$.

According to the existing ideas about the principles and sequence of stages in dental implant treatment, it is important to assess the stability of the implants before starting orthopedic treatment $[9,10]$. 
The aim of the study was to assess the stability of implants in the lateral parts of the dentition before orthopedic treatment.

Material and Methods. One hundred twenty-six patients (67 males and 59 females) were examined and divided into five groups. Group 1 included 18 people with 36 implants (18/36) aged 35-44 years; Group 2 included 21 people with 48 implants (21/48) aged 45-54 years; Group 3 included 31 people with 149 implants (31/149) aged 55-64 years; and Group 4 included 34 people with 153 implants (34/153) aged $65-74$ years. Group 5 included 22 people aged 20-34 years who, for various reasons (such as orthodontic preparation for prosthetics, financial problems) did not receive orthopedic structures for implants in the prescribed time. Most cases in this group had implants that had been in place for 1.5 to 2.5 years.

The secondary stability of 425 implants (Konmet Ltd, Russian Federation, certificate of compliance with the requirements of the European Directive 93/42/EEC on medical devices) replacing maxillary and mandibular molars and premolars was studied in detail, provided that the primary stability was not lower than 30 ISQ (implant stability quotient) units at the time of installation. None of the patients included in the study had concomitant somatic pathology that could affect the state of bone tissue. The implantation protocol did not include the use of osteoplastic materials.

The stability of the implants was assessed with the Penguin RFA device (Integration Diagnostics Sweden AB,
Gothenburg, Sweden), which measures the magnetic resonance frequency analysis (RFA) of a reusable MulTipeg pin using non-contact technology. The frequency is expressed in ISQ units on a scale from 1 to 99. High stability is indicated by a score above 70-75 ISQ.

The study was conducted 3 months after implantation in mandible and 5 months after implantation in the maxilla, and was preceded by orthopedic treatment.

To predict the results of osseointegration of the installed dental implants, X-rays were taken with a Personica-II high-frequency X-ray machine with a QF/30-1 PRELIMINARY monoblock (Stockholm, Sweden) and a Leica Dental mobile radiovisiograph (Leica Microsystems, Milan, Italy) in various modes to determine the bone density in Hounsfield units.

The data were statistically processed using the standard mathematical software program Statistics for Windows 6.0 (StatSoft, USA). The reliability of intergroup differences was determined according to Student's criterion $(p<0.05)$.

Results and Discussion. The results of the study revealed certain patterns. Comparing the data on the stability of the installed maxillary and mandibular dental implants, there was an excess of the ISQ indicators on the lower jaw in all the examined groups (Table 1). These indicators are as expected and can be explained by the different density and architectonics of the bone tissue, as well as the timing of the study.

Implant stability indicators (ISQ) on the upper and lower jaw ( $\mathbf{M} \pm \mathbf{m})$

\begin{tabular}{|c|c|c|c|c|c|}
\hline \multirow{2}{*}{ Implantation area } & \multicolumn{5}{|c|}{ Age group (years) } \\
\cline { 2 - 6 } & $\begin{array}{c}35-44 \\
(\mathrm{n}=18)\end{array}$ & $\begin{array}{c}45-54 \\
(\mathrm{n}=21)\end{array}$ & $\begin{array}{c}55-64 \\
(\mathrm{n}=31)\end{array}$ & $\begin{array}{c}65-74 \\
(\mathrm{n}=34)\end{array}$ & $\begin{array}{c}25-34 \\
(\mathrm{n}=22)\end{array}$ \\
\hline $1.4,2.4$ & $76.6 \pm 2.2$ & $77.9 \pm 2.1$ & $77.7 \pm 2.2$ & $74.6 \pm 2.2$ & $78.6 \pm 1.9$ \\
\hline $3.4,4.4$ & $84.7 \pm 2.6^{*}$ & $85.0 \pm 2.5^{*}$ & $84.3 \pm 1.9^{*}$ & $82.7 \pm 3.1^{*}$ & $81.1 \pm 2.2$ \\
\hline $1.5,2.5$ & $77.6 \pm 2.1$ & $76.3 \pm 2.3$ & $76.9 \pm 2.1$ & $73.5 \pm 2.6$ & $78.7 \pm 2.2$ \\
\hline $3.5,4.5$ & $85.4 \pm 3.0^{*}$ & $83.9 \pm 2.6^{*}$ & $83.1 \pm 2.0^{*}$ & $82.5 \pm 3.1^{*}$ & $80.4 \pm 3.3$ \\
\hline $1.6,2.6$ & $75.5 \pm 2.3$ & $74.8 \pm 2.1$ & $70.9 \pm 2.1$ & $48.4 \pm 1.2$ & $76.2 \pm 2.6$ \\
\hline $3.6,4.6$ & $83.7 \pm 3.1^{*}$ & $82.9 \pm 2.9^{*}$ & $76.1 \pm 2.4^{*}$ & $59.3 \pm 1.8^{* *}$ & $77.4 \pm 2.5$ \\
\hline $1.7,2.7$ & $74.6 \pm 1.9$ & $70.1 \pm 1.7$ & $62.3 \pm 1.9$ & $27.9 \pm 1.8$ & $82.1 \pm 1.7$ \\
\hline $3.7,4.7$ & $82.5 \pm 2.8^{*}$ & $76.2 \pm 2.3^{*}$ & $72.5 \pm 1.7^{*}$ & $28.6 \pm 1.6$ & $86.3 \pm 2.0$ \\
\hline
\end{tabular}

Note. The significance of the differences between the upper and lower teeth at: ${ }^{\star}-p<0.05,{ }^{* \star}-p<0.001$.

The stability features of dental implants replacing missing teeth in the lateral parts of the jaws were analyzed. In Group 1 and Group 2, the stability indicators of all implants indicated high-quality osseointegration (Table 2). In Group 3 (55-64 years), the ISQ values decreased towards the distal parts of the jaw, and the difference in stability of maxillary and mandibular dental implants replacing first and second premolars and first molars compared with second molars was statistically significant.

Implant stability indicators (ISQ) when comparing teeth of the same dentition (M $\pm m$ )

\begin{tabular}{|c|c|c|c|c|c|}
\hline \multirow{2}{*}{ Implantation area } & \multicolumn{5}{|c|}{ Age group (years) } \\
\cline { 2 - 6 } & $\begin{array}{c}35-44 \\
(\mathrm{n}=18)\end{array}$ & $\begin{array}{c}45-54 \\
(\mathrm{n}=21)\end{array}$ & $\begin{array}{c}55-64 \\
(\mathrm{n}=31)\end{array}$ & $\begin{array}{c}65-74 \\
(\mathrm{n}=34)\end{array}$ & $\begin{array}{c}25-34 \\
(\mathrm{n}=22)\end{array}$ \\
\hline $1.4,2.4$ & $76.6 \pm 2.2$ & $77.9 \pm 2.1^{\mathrm{m}}$ & $77.7 \pm 2.2^{\mathrm{mmm}}$ & $74.6 \pm 2.2^{\mathrm{mmm}}$ & $78.6 \pm 1.9$ \\
\hline $3.4,4.4$ & $84.7 \pm 2.6$ & $85.0 \pm 2.5$ & $84.3 \pm 1.9^{\mathrm{v}}$ & $82.7 \pm 3.1^{\mathrm{vvv}}$ & $81.1 \pm 2.2$ \\
\hline $1.5,2.5$ & $77.6 \pm 2.1$ & $76.3 \pm 2.3^{\mathrm{m}}$ & $76.9 \pm 2.1^{\mathrm{mmm}}$ & $73.5 \pm 2.6^{\mathrm{mmm}}$ & $78.7 \pm 2.2$ \\
\hline $3.5,4.5$ & $85.4 \pm 3.0$ & $83.9 \pm 2.6$ & $83.1 \pm 2.0^{\mathrm{v}}$ & $82.5 \pm 3.1^{\mathrm{vvv}}$ & $80.4 \pm 3.3$ \\
\hline $1.6,2.6$ & $75.5 \pm 2.3$ & $74.8 \pm 2.1$ & $70.9 \pm 2.1^{\mathrm{mm}}$ & $48.4 \pm 1.2^{\mathrm{mmm}}$ & $76.2 \pm 2.6$ \\
\hline $3.6,4.6$ & $83.7 \pm 3.1$ & $82.9 \pm 2.9$ & $76.1 \pm 2.4$ & $59.31 .8^{\mathrm{vvv}}$ & $77.4 \pm 2.5^{\mathrm{v}}$ \\
\hline $1.7,2.7$ & $74.6 \pm 1.9$ & $70.1 \pm 1.7$ & $62.3 \pm 1.9$ & $27.9 \pm 1.8$ & $82.1 \pm 1.7$ \\
\hline $3.7,4.7$ & $82.5 \pm 2.8$ & $76.2 \pm 2.3$ & $72.5 \pm 1.7$ & $28.6 \pm 1.6$ & $86.3 \pm 2.0$ \\
\hline
\end{tabular}

Note. The significance of differences between 7 and $4-6$ teeth of the upper jaw at: $m-p<0.05, m m-p<0.01, m m m-p<0.001$; the significance of differences between 7 and $4-6$ teeth of the lower jaw at: ${ }^{v}-p<0.05$, vwv $-p<0.001$. 
In Group 4 (65-74 years), the stability indicators of implants replacing molars were significantly lower than those of implants replacing premolars, while the difference between second molars and teeth 4-6 in both jaws was statistically significant $(p<001)$. It should be noted that the dental implants replacing premolars in this age group had ISQ values above 70 .

Group 5 patients, who had no functional load on dental implants for periods of 1.5-2.5 years due to a lack of orthopedic treatment, exhibited sufficiently high rates of osseointegration.

Our findings indicated that in groups 1 and 2 there was no negative effect of delayed functional load on the stability of dental implants, which is consistent with both the experimental data and the clinical observations for implantation systems $[10,11]$.

The stability of dental implants in all groups revealed a tendency to decrease with age. A statistically significant difference in the ISQ values of implants located in the first and second molar region was observed when comparing patients of Group 4 (65-74 years) with the other groups. In persons over 65 years of age only in the areas of implantation $1.4,2.4 ; 3.4,4.4 ; 1.5,2.5$ and $3.5,4.5$ values of ISQ indicators remained at the level above 70 .

This study showed that a sufficient volume of bone tissue without pronounced atrophy and osteoporosis provides favorable conditions for dental implantation in younger and older age groups, and is confirmed by the results of X-ray examination. The architectonics of the bone tissue adjacent to dental implants in patients in Groups 1 and 2 were shown to be identical to native bone in the corresponding intact areas of the jaw.
A qualitatively different situation is observed in patients over 65 years of age. In this age group, implantation in the area of the missing molars is less stable than in the other age groups. Implantation in the area of missing second molars is the most problematic because of the significant loss of bone tissue in this area with adentia and the low regenerative capabilities of patients in the older age group.

Conclusions. There was a tendency for the stability of dental implants to decrease in a distal direction in all age groups. In all groups, the stability of maxillary dental implants was lower than that of the mandibular implants. In the group of patients aged over 65 years, dental implants replacing premolars were more than twice as stable as those replacing second molars, which indicates the feasibility of manufacturing single orthopedic structures. An alternative treatment plan would be the production of removable structures with external screw fixation, which could be easily removed if necessary.

The diagnostic value of frequency-resonance testing of the stability of domestically produced implant systems using the Penguin RFA apparatus has been established, which makes it possible to objectively, quickly, and accurately record the degree of change in the mechanical and biological stability of dental implants at different stages of osseointegration when choosing the most optimal prosthesis design.

Experimental animal procedures. The work followed the ethical principles set forth in the Helsinki Declaration of the World Medical Association (1964, as amended in 2000); the study was carried out in accordance with the basic rules for conducting clinical trials and the positive conclusion of the local ethics committee.

Disclosures: The authors declare no conflict of interest.

Acknowledgements. We thank Helen Jeays, BDSc AE, from Edanz (www.edanz.com/ac) for editing a draft of this manuscript.

\section{References}

1. Bassir S. H., El Kholy K., Chen C. Y., Lee K. H., Intini G. Outcome of early dental implant placement versus other dental implant placement protocols: A systematic review and meta-analysis. Journal of Periodontology. 2019;90(5):493-506 https://doi.org/10.1002/JPER.18-0338

2. Do T. A., Le H. S., Shen Y. W. Huang H. L., Fuh L.J. Risk Factors related to Late Failure of Dental Implant-A Systematic Review of Recent Studies. International Journal of Environmental Research and Public Health. 2020;17(11):3931. https://doi.org/10.3390/ijerph17113931

3. Insua A., Monje A., Wang H. L., Miron R. J. Basis of bone metabolism around dental implants during osseointegration and peri-implant bone loss. Journal of Biomedical Materials Research. Part A. 2017;105(7):2075-2089. https://doi.org/10.1002/jbm.a.36060

4. Garunov M. M., Sevbitov A. V., Dolgalev A. A., Sirak S. V., Solovyeva O. A. [et al.] Clinical and radiographic assessment of osteointegration of dental implants after remodeling of the perimplant zone. Medicinskii vestnik Severnogo Kavkaza. - Medical News of North Caucasus. 2019;14(4):699-700 https://doi.org/10.14300/mnnc.2019.14174

5. Alifarag A. M., Lopez C. D., Neiva R. F., Tovar N., Witek L. [et al.] Atemporal osseointegration: Early biomechanical stability through osseodensification. Journal of Orthopaedic Research. 2018;36(9):2516-2523 https://doi.org/10.1002/jor.23893

6. Asa'ad F., Pelanyte G., Philip J., Dahlin C., Larsson L. The Role of Epigenetic Functionalization of Implants and Biomaterials in Osseointegration and Bone Regeneration-A Review. Molecules. 2020;25(24):5879. https://doi.org/10.3390/molecules25245879

7. Glauser R., Sennerby L., Meredith N., Rée A., Lundgren A. [et al.] Resonance frequency analysis of implants subjected to immediate or early functional occlusal loading. Successful vs. failing implants. Clinical Oral Implants Research. 2004:15(4):428-34

https://doi.org/10.1111/j.1600-0501.2004.01036.x

8. Kulakov A. A., Brailovskaia T. V., Stepanova I. I., Kasparov A. S., Shcherchkov S. V. [et al.] Clinical aspects of bone augmentation procedures in complex topography in patients with partial or full teeth loss. Stomatologiya. Stomatology. 2013;92(3):30-33.

9. Kulakov A. A., Kasparov A. S., Porfenchuk D. A. The early functional loading protocol's efficiency for various dental implants. Klinicheskaya stomatologiya. - Clinical Dentisty. 2020;(2):61-66. https://doi.org/10.37988/1811-153X 2020 261

10. Benic G. I., Mir-Mari J., Hämmerle C. H. Loading protocols for single-implant crowns: a systematic review and metaanalysis. The International Journal of Oral \& Maxillofacial Implants. 2014:29(Suppl):222-38.

https://doi.org/10.11607/jomi.2014suppl.g4.1

11. Sirak S. V., Didenko M. O., Sirak A. G., Shchetinina E. E., Sirak E. S. [et al.] Influence of load on modeling and remodeling of bone tissue in experimental perimplantitis. Medicinskii vestnik Severnogo Kavkaza. - Medical News of North Caucasus. 2020;15(3):364-368. https://doi.org/10.14300/mnnc.2020.15086

\section{About autors:}

Remizova Anna Aleksandrovna, MD, PhD, Professor, Head of the Department of dentistry № 3;

tel.: +79284951222; e-mail: annasas@mail.ru; https://orcid.org/0000-0001-5951-9454 
Dzgoeva Madina Georgievna, MD, PhD, Professor, Head of the Department of dentistry № 1 ; tel.: +79188232325; e-mail: madina-dzgoeva@mail.ru; https://orcid.org/0000-0002-0247-1901

Sirak Sergey Vladimirovich, MD, PhD, Professor, Head of the Department of dentistry;

tel.: +78652350551; e-mail: sergejsirak@yandex.ru; https://orcid.org/0000-0002-4924-5792

Bitarov Pavel Alanovich, postgraduate student;

tel.: +79888777087; e-mail: pavel.bitarov@mail.ru; https://orcid.org/0000-0002-2212-0316

Sirak Alla Grigorievna, MD, PhD, Professor, Head of Departament of histology; tel.: +78652356219; e-mail: kafedragist@yandex.ru

Tingaeva Yulia Igorevna, resident;

tel.: +79272744000; e-mail: iulia.tingaeva@yandex.ru; https://orcid.org/0000-0001-8471-0146

Andreev Anton, Senior Laboratory Assistant of the Department of dentistry; tel.: +78652350551; e-mail: andreev_ant22@yandex.ru

(c) Group of authors, 2021

UDC 616.31-089

DOI - https://doi.org/10.14300/mnnc.2021.16040

ISSN - 2073-8137

\title{
MODIFICATIONS OF THE SPLIT BONE TECHNIQUE FOR LATERAL RIDGE AUGMENTATION
}

\author{
Muraev A. A. ${ }^{1}$, Polevoy V. V. ${ }^{2}$, Ivanov S. Yu. ${ }^{1,3}$, Dolgalev Al. Al. ${ }^{4}$, \\ Muhametshin R. F. ${ }^{1}$, Gazhva S. I. ${ }^{5}$, Boyko E. M. ${ }^{4}$, Zelensky V. I. ${ }^{4}$ \\ ${ }^{1}$ Peoples' Friendship University of Russia, Moscow, Russian Federation \\ ${ }^{2}$ Central Clinical Hospital of the Presidential Administration of Russian Federation, \\ Moscow, Russian Federation \\ ${ }^{3}$ I. M. Sechenov First Moscow State Medical University (Sechenov University), \\ Russian Federation \\ ${ }^{4}$ Stavropol State Medical University, Russian Federation \\ ${ }^{5}$ Privolzhsky Research Medical University, Nizhny Novgorod, Russian Federation
}

\section{МОАИФИЦИРОВАННЫЕ МЕТОАЫ МЕЖКОРТИКААЬНОЙ ОСТЕОТОМИИ И РАСЩЕПАЕНИЯ ААЬВЕОАЯРНОГО ГРЕБНЯ}

\author{
А. А. Мураев ${ }^{1}$, В. В. Полевой ${ }^{2}$, С. Ю. Иванов ${ }^{1,3}$, А. А. Аолгалев 4 , \\ Р. Ф. Мухаметшин ${ }^{1}$, С. И. Гажва ${ }^{5}$, Е. М. Бойко ${ }^{4}$, В. И. Зеленский ${ }^{\prime}$
}

${ }^{1}$ Российский университет Аружбы народов, Москва, Российская ФеАерация

2 Центральная кАиническая больница ААминистрации ПрезиАента

Российской ФеАерации, Москва, Российская ФеАерация

3 Первый Московский госуАарственный меАицинский университет им. И. М. Сеченова (Сеченовский Университет), Российская ФеАерация

${ }^{4}$ Ставропольский госуАарственный меАицинский университет, Российская ФеАерация

5 Приволжский научно-исслеАоватеАьский МеАицинский Университет Министерства зАравоохранения Российской ФеАерации, Нижний НовгороА, Российская ФеАерация

This article presents a modified approach to the method of intercortical osteotomy and splitting of the alveolar ridge for use when the classical approach does not solve the problem of atrophy. The standard protocol for osteotomy with alveolar ridge splitting is not universal for all clinical situations. We operated on 33 patients using five modifications for splitting the alveolar ridge: lingual, vestibular and lingual, mesial, rotation of the bone block by $180^{\circ}$, and lingual with displacement of the osteotomy line.

In all cases, the alveolar ridge width reached $7.1 \pm 0.7 \mathrm{~mm}$, sufficient for installation of dental implants with a regular or wide platform $(3.75-5.0 \mathrm{~mm}$ ), and only $6.1 \%$ of implants failed. Based on the biological principles of alveolar bone regeneration, the indications for the use of intercortical osteotomy and splitting of the alveolar ridge have been expanded for use in various clinical situations.

Keywords: dental implants, alveolar bone loss, sticky bone, ridge-split technique, alveolar ridge augmentation, piezoelectric bone surgery, bone tissue grafts

Представлены модифицированные подходы метода межкортикальной остеотомии и расщепления альвеолярного гребня, когда классический подход не позволяет решить проблему атрофии. Поскольку стандартный протокол проведения остеотомии с расщеплением альвеолярного гребня не является универсальным для всех клинических ситуаций. Нами были прооперированы 33 пациента с применением 5 различных модификаций расщепления альвеолярного гребня: оральный, вестибулярный и оральный, мезиальный, с ротацией костного блока на $180^{\circ}$, язычный со смещением линии остеотомии. 